\title{
Possibilities of rice husk ash to be used as reinforcing filler in polymer sector - a review
}

\section{Posibilidades de usar la ceniza de cascarilla de arroz como reforzante en el sector de polímeros - una revisión}

\author{
Natalia Cardona-Uribe ${ }^{1}$, Cindy Arenas-Echeverri ${ }^{2}$, Mariluz Betancur ${ }^{3}$, Leyla Jaramillo ${ }^{4}$, \\ Juan Martínez
}

\footnotetext{
${ }^{1}$ Grupo de Investigaciones Ambientales, Universidad Pontificia Bolivariana, Colombia. Email: natalia.cardonaur@upb.edu.co ${ }^{2}$ Grupo de Investigaciones Ambientales, Universidad Pontificia Bolivariana, Colombia. Email: cindy.arenas@upb.edu.co ${ }^{3}$ Grupo de Investigaciones Ambientales, Universidad Pontificia Bolivariana, Colombia. Email: mariluz.betancur@upb.edu.co ${ }^{4}$ Grupo de Investigación en Calidad, Metrología y Producción, Instituto Tecnológico Metropolitano, Colombia. Email: leylajaramillo@itm.edu.co

${ }^{5}$ Grupo de Investigaciones Ambientales, Universidad Pontificia Bolivariana, Colombia. Email: juand.martinez@upb.edu.co
}

RECEIVED: February 18, 2016. ACCEPTED: May 30, 2017. FINAL VeRSION: October 29, 2017.

\begin{abstract}
This work presents a literature review of the synthetic silica production pathways which are classified in thermal (also known as pyrogenic) and wet. They lead to different commercial references with different properties depending not only on the process conditions but also on the raw material characteristics. Based on the aforementioned, a simile is made with the rice husk ash (RHA) obtained from rice husk combustion, and its main physical-chemical properties required for its use in polymer sector are also shown. In this sense, this work shows a wide review of chemical composition, surface area, molecular structure (amorphous or crystalline) and particle size of different RHA found in literature. Finally, the mechanical performance of both thermoplastics and elastomers reinforced with RHA reported in literature is also described and compared with those composites reinforced with some commercial silica.
\end{abstract}

KEYWORDS: Reinforcing fillers; rice husk ash; rubber; silica; thermoplastic.

\section{RESUMEN}

Este trabajo presenta una revisión de las rutas de obtención de sílice sintética, clasificadas como de tipo térmico (también conocido como pirogénico) y líquido, las cuales dan lugar a diferentes referencias con diversas propiedades dependiendo, no solo de las condiciones del proceso sino también de las características de la materia prima. Con base en lo anterior, se hace un símil con la ceniza cascarilla de arroz (CCA) obtenida a partir de la combustión de la cascarilla de arroz, y se resaltan las principales propiedades físico-químicas para su utilización como reforzante en el sector de polímeros. En este sentido, este trabajo muestra una amplia revisión de la composición química, área superficial, estructura molecular y tamaño de partículas de diferentes CCA encontradas en la literatura. Finalmente, se describe el desempeño mecánico de materiales termoplásticos y elastómeros reforzados con CCA reportados en la literatura y comparados con compuestos reforzados con algunas sílices comerciales.

PALABRAS CLAVE: Carga reforzante; caucho; ceniza de cascarilla de arroz; sílice; termoplásticos.

ISSN Impreso: 1657 - 4583, En Línea: 2145 - 8456

Este artículo puede compartirse bajo la licencia CC BY-ND 4.0 y se referencia usando el siguiente formato: N. Cardona, C. Arenas, M. Betancur, L. Jaramillo, J. Martínez, "Possibilities of rice husk ash to be used as reinforcing filler in polymer sector - a review," Rev. UIS Ing., vol. 17, no. 1, pp. 127-142, 2018. Doi: https://doi.org/10.18273/revuin.v17n1-2018012 


\section{INTRODUCTION}

Rice is the second agricultural product cultivated worldwide after corn [1]. Global paddy rice production in 2016 was 752 million tons (499 million tons, milled basis), planted in 163 million hectares all along the world. This production was 3.9 million tons more than December forecasts and $1.6 \%$ above the same period of 2015 [2]. According to FAO, the global paddy production in 2017 will be 755 million tons [3].

Colombia is the third rice producer in south America [3]. According to DANE, the planting rice area in 2016 was 570,802 hectares and the paddy rice production was 2.97 million tons [4], which supposed 594,000 tons of rice husk (RH). RH is a byproduct of agriculture industry which depicts $20 \%$ of the whole grain rice. RH low density $\left(\sim 125 \mathrm{~kg} / \mathrm{m}^{3}\right)$ [5], difficults its handling and appropriate disposal. In many countries, this agricultural waste is disposed in vacant lots and in the riverbed causing environmental impacts such as landscape damages and fauna and flora affectations [6], [7].

On the other hand, $\mathrm{RH}$ has interesting characteristics from the energy and materials recovery point of view. In general terms, RH is composed by 33 wt.\% cellulose, 25 wt.\% lignin, 22 wt.\% hemicellulose and 20 wt.\% inorganics [7]-[10]. Some common alternatives for the RH valorization involve its use as: i) substrate in greenhouse crops (moisture retention in crops and controlling plant height or stem length) [11], [12], ii) fertilizer [13], iii) animal food [14]-[16], iv) beds for livestock and poultry industry (floor covering in farms) [17], [18] and v) chipboards [19], among others. Likewise, $\mathrm{RH}$ is attractive as fuel for conducting the rice drying process [20]-[23]. Its heating value (between 15 and $17 \mathrm{~kJ} / \mathrm{kg}$ ) and its higher volatile matter (between 60 and 65 wt.\%) make the RH a reasonable feedstock for combustion process in spite of its higher ash content (between 16 and 20 wt.\%). The resulting rice husk ash (RHA) has high silica content (>90 wt.\%) [7], [24]-[27] and hence, it is attractive as a raw material for cement [28]-[30], polymers [31]-[34], adsorbents [14], [28], [35], among others.

Beside all those applications, different processes have been developed for the preparation of silica from RH as reviewed by Soltani et al. [28]. In general terms, there are three different treatments applied to $\mathrm{RH}$ for the silica production: thermochemical, chemical and biological treatments. Within thermochemical treatments is found pyrolysis, gasification and combustion, being the last one the more attractive and studied process for the $\mathrm{SiO}_{2}$ production with minor unburnt compounds [36], [37]. Combustion of RH is not only a self-sustaining process minimizing the requirements for auxiliary fuel, but also allows the easy temperature control which is necessary to obtain amorphous structure RHA [6], [38], [39]. In this sense, amorphous nature of RHA is favored at temperatures lower than $700^{\circ} \mathrm{C}$ [37], [40]. In the case of chemical treatments, different acid and even basic agents are also used to remove the organic matter to produce a purified silica [41], while biochemical treatments use microbial fermentation to decompose the organic matter and finally obtain the amorphous silica [42].

The aim of this review is to present the most important properties of silica and RHA for its use in polymer applications. A brief revision on the commercial silica processes is showed as well as the main properties for its use in polymers. The RHA properties (chemical composition, surface area, molecular structure (crystalline or amorphous) and particle size) from RH combustion is also reviewed as well as the mechanical performance of both thermoplastics and elastomers filled with RHA.

\section{COMMERCIAL SILICA}

After carbon, silica is the second main element found in the earth crust. Silica is found in oxide or silicate form, in amorphous or crystalline structure [24]. In general terms, there are two types of silica, natural and synthetic. Natural silica is found in minerals such as quartz and flint, and also in plants such as bamboo, rice and barley. Synthetic silica is produced by different routes obtaining fibers, sheets, gel and powder. Those synthetic process can be classified in two routes: thermal and wet processes. Depending on the raw material and the applied pathway, it could be possible to obtain different kinds of synthetic silica such as sols or colloidal, gel, pyrogenic, and precipitated silica [43], [44] as is shown in Figure 1.

Pyrogenic silica process is one of the most widely used for synthetic silica production. This process consists in the synthesis of silica in a vapor phase at high temperatures [45]. The silica is prepared from $\mathrm{SiCl}_{4}$ and is known as fumed silica while silica obtained from quartz sand is known as arc silica. More details of fumed silica are found in section 2.1. Arc silica, also called fused silica, is produce by reducing quartz sand or other silica containing material with coke at temperatures above $2000{ }^{\circ} \mathrm{C}$ in an electrical arc furnace. Then, volatile $\mathrm{SiO}$ reacts with oxygen from air or steam in a second step to produce $\mathrm{SiO}_{2}$, as showed in reaction (1) and (2) [43]:

$$
\begin{gathered}
\mathrm{SiO}_{2}+\mathrm{C} \rightarrow \mathrm{SiO}+\mathrm{CO} \\
\mathrm{SiO}+\mathrm{CO}+\mathrm{O}_{2} \rightarrow \mathrm{SiO}_{2}+\mathrm{CO}_{2}
\end{gathered}
$$

On the other hand, silica gel and colloidal (sols) are considered as hydrated silicas, and they are obtained by wet processes. As well as pyrogenic silica (thermal 


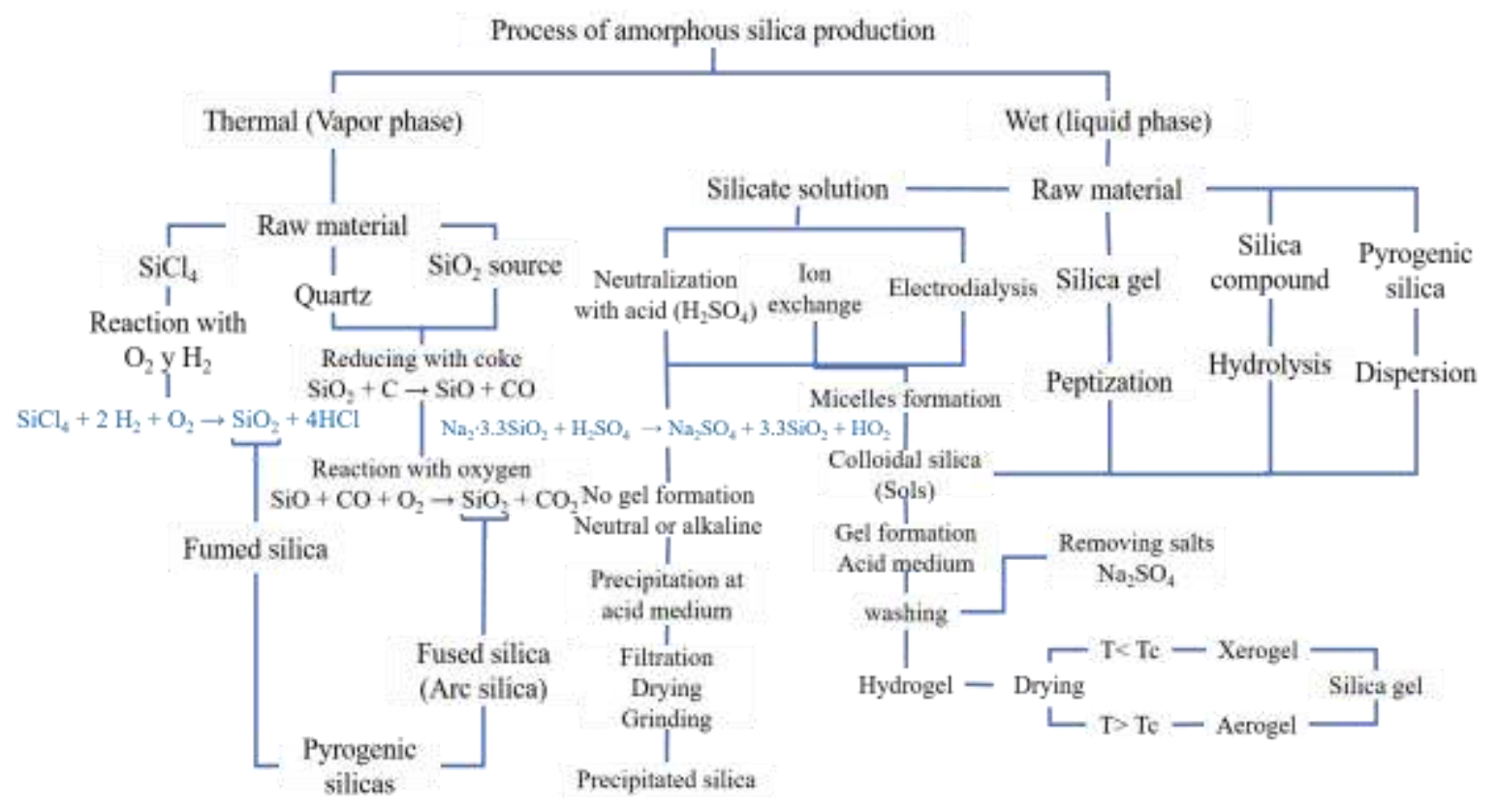

Figure 1. Different commercial silica routes of production (adapted from [45]).

processes), hydrated silicas are produce from different raw materials and routes. Colloidal silicas are obtained from silicate solution (generally $\mathrm{Na}_{2} \mathrm{SiO}_{3}$ ) followed by the separation of silica from the silicate. That step could be carried out by three different ways: i) a neutralization with acid (for instance $\mathrm{H}_{2} \mathrm{SO}_{4}$ ), ii) an ion exchange with cation ion exchange resin and iii) an electrodialysis with cation exchange membrane. Once the silica is separated, the nucleation takes place followed by polymerization of silicate tetrahedron in a random amorphous manner until forms small spheroids called micelles. The solution with micelles is known as colloidal silica or silica sol (suspension of $\mathrm{SiO}_{2}$ particles size between 100 and 150 $\mathrm{nm}$ ) [45]. The liquid where silica is dispersed can be water or organic solvent which are known as hydrosol or organosols respectively [44].

Similarly, colloidal silica may also be produced by: i) peptization of silica gel, ii) hydrolysis of a silica compound and iii) dispersion of a pyrogenic silica as shown in Figure 1 [45].

On the other hand, Walter Patrick developed the original process of silica gel production in 1919 [46]. Silica gel is prepared from the neutralization of sodium silicate solution by an acid reagent (generally $\mathrm{H}_{2} \mathrm{SO}_{4}$ ). From the hydrosol, the gel is formed when occurs the interactions of separate micelles through hydrogen bonds and interparticle condensation. This step is known as gelation and produce the hydrogel. After the gel formation, the solid gel is washed and dried at specific conditions to obtain the desired physical properties such as porosity, pore size and surface area [45]. In general terms, there are three types of silica gel: hydrogel, xerogels and aerogels. The first one is produced in the gelation step and is known as hydrogel or alcogel whether the solvent is water or an alcohol respectively, while the other gels (xerogel and aerogel) depend on the method for extraction the liquid from the solid network. The xerogel is formed when the hydrogel is dried under critical temperature $\left(\mathrm{T}_{\mathrm{c}}\right)$, resulting in a shrinkage of the structure and reducing the porosity. Whereas the aerogel, is formed when the liquid is extracted above $T_{c}$ of the solvent to prevent any collapse or shrinkage in the structure [44].

Within commercial silicas references, it is common to find pyrogenic silicas with similar physical properties to others precipitated silica or silica gel. This fact suggest that differences in properties not only depends on the preparation method [43], but also on the primary particle size and the way in which particles are aggregated or agglomerated [44]. Agglomeration refers to the sharing of a side between two particles (loosely attached), while aggregation is related to the linking of particles or agglomerates to form stable aggregates (hard to break). Furthermore, the structure parameter is a function of the aggregate size, shape and pore volume [47].

The structure is determined by an oil absorption test (usually named as oil absorption number (OAN)) given as a result 5 different levels: i) very low structure (VLS) when OAN is less than $75 \mathrm{~mL} / 100 \mathrm{~g}$, ii) low structure (LS) for OAN between 75 and $125 \mathrm{~mL} / 100 \mathrm{~g}$, iii) medium structure (MS) when OAN is between 125 and 175 
$\mathrm{mL} / 100 \mathrm{~g}$, iv) high structure (HS) for OAN between 175 and $200 \mathrm{~mL} / 100 \mathrm{~g}$ and $\mathrm{v}$ ) very high structure (VHS) when OAN is above $200 \mathrm{~mL} / 100 \mathrm{~g}$ [48]. That way, the chainlike arrangement of primary particles results in a non-porous structure [44]. For instance, pyrogenic silicas do not show any porosity because of their aggregation in a chain-like form, while silica gels show porous structure [44], [49]. As it is shown in Table 1 silica gel has the highest surface area compared to fumed, arc and precipitated silica due to its high internal porosity.

There are two types of surface area, internal and external; however, the degree of reinforcement polymer filled with silica is related to silica external surface area because internal surface is inaccessible to the large polymer molecule. This characteristic may be the reason why silica gel is not an effective reinforcing filler compare with precipitated silica [43].

Table 1 also shows that hydrated silicas (gel and precipitated) has higher silanol density than pyrogenic silicas (fumed and arc silicas). This is because the high temperature used in pyrogenic processes makes silanol to condensate to form siloxane groups. The presence of lower temperature and vapor water results in rehydroxylation which increases silanol groups.

\subsection{Fumed silica}

As mentioned before, fumed silica is part of pyrogenic silica produced by thermal process in a vapor phase. Fumed silica is produced by burning $\mathrm{SiCl}_{4}$ with hydrogen and oxygen, as showed in reaction (3):

$$
2 \mathrm{H}_{2}+\mathrm{O}_{2}+\mathrm{SiCl}_{4} \rightarrow \mathrm{SiO}_{2}+4 \mathrm{HCl}
$$

The key properties such as particle size and surface area is controlled by the reactants ratio. This process was developed by Degussa and the silica obtained in this process is known as Aerosil ${ }^{\circledR}$ [44]. The first particles are formed when $\mathrm{SiCl}_{4}$ are burned in a flame and then fuse among them irreversibly given place to secondary particles (aggregates with a three-dimensional chainlike). After that, the silica is collected in cyclones or filters and separated from the residual $\mathrm{HCl}$ by treating them with moist hot air [43]. This process leads to the production of nonporous and amorphous high purity silica ( $99 \mathrm{wt} \%$ ). The surface area BET of fumed silicas varied from 50 to $600 \mathrm{~m}^{2} / \mathrm{g}$ and the average particle size is between 5 and $50 \mathrm{~nm}$, depending on the reaction conditions [44]. Generally, fumed silica with surface area below $300 \mathrm{~m}^{2} / \mathrm{g}$ is nonporous while silica with a surface area above $300 \mathrm{~m}^{2} / \mathrm{g}$ exhibits some microporosity [43].
One advantage of fumed silica is that there are different grades depending on the final application. For instance, some of them are designed for highly transparent products, allowing to obtain a versatile product that could be impregnated by any color [50], [51].

There are two types of fumed silica commercially available, hydrophilic, and hydrophobic for elastomers reinforcement [52]. Hydrophilic is used in products that can be wetted with water and is produced during normal flame hydrolysis of silicon tetrachloride, while hydrophobic silica is produced by reacting hydrophilic silica with organosilanes and is applied in products that cannot be wetted. Generally, hydrophobized silica is expected to be better reinforcement than hydrophilic silica [43].

\subsection{Precipitated silica}

Precipitated silica is produced by wet process: starting from the acidulation of $\mathrm{Na}_{2} \mathrm{SiO}_{3}$ solution with $\mathrm{H}_{2} \mathrm{SO}_{4}$ under alkaline conditions or simply, from a colloidal silica. The process seems to be similar to that of the silica gel production mentioned before, but in this case, the formation of gel is avoided and the precipitation is stimulated [43], [44]. The main difference is that silica gel is produced under acidic conditions, while precipitated silica is carried out in neutral or alkaline medium. The precipitation occurs when the first particles (micelles) are formed and then start to grow in size as more silica is precipitated on the surface micelles [43]. This precipitation process leads to the production of a white powder with almost 87 wt. $\%$ of $\mathrm{SiO}_{2}$ and 10 wt. $\%$ of water which is bounded into the molecular structure or physically adsorbed onto the surface [53].

The properties of the precipitated silica can be influenced by the plant equipment design and process parameters. The production process consists of the following steps: precipitation, filtration, drying, grinding, and, in some cases, compacting and granulation [45].

Regardless of the production method, all synthetic silicas are amorphous in nature, colourless, odourless and tasteless. They are considered polymers produced by interlinking of $\mathrm{SiO}_{4}$ tetrahedron which ends in siloxane and silanol groups [43]. In conclusion, there are many kinds of commercial silicas which confer different reinforcing grades and properties to the final product (reinforced polymer). Table 2 shows the surface area and reinforcing grade reported by some producers of different commercial silica references. 
Table 1. Properties of some different types of silicas (adapted from [43], [44]).

\begin{tabular}{|c|c|c|c|c|}
\hline \multirow{2}{*}{ Characteristics } & \multicolumn{2}{|l|}{ Vapor process } & \multicolumn{2}{|l|}{ Liquid process } \\
\hline & Fumed & Arc (fuse) & Precipitated & Gel \\
\hline Surface area BET $\left(\mathrm{m}^{2} / \mathrm{g}\right)$ & $50-600$ & $25-300$ & $30-800$ & $250-1000$ \\
\hline Size particle $(\mathrm{nm})$ & $5-50$ & $5-500$ & $5-100$ & $3-20$ \\
\hline Size aggregates/ agglomeration $(\mu \mathrm{m})$ & & $2-15$ & $1-40$ & $1-20$ \\
\hline Density $(\mathrm{g} / \mathrm{ml})$ & 2.2 & 2.2 & $1.9-2.1$ & 2.0 \\
\hline Mean pore diameter $(\mathrm{nm})$ & $\begin{array}{l}\text { Non-porous } \\
\text { (below } 300 \mathrm{~m}^{2} / \mathrm{g} \text { ) } \\
\text { Micro porosity } \\
\left(\text { above } 300 \mathrm{~m}^{2} / \mathrm{g} \text { ) }\right.\end{array}$ & Non-porous & $>30$ & $\begin{array}{l}2-20 \text { (xerogel) or } \\
>25 \text { (aerogel) }\end{array}$ \\
\hline $5 \% \mathrm{pH}$ & $3.6-4.3$ & $3.5-4.2$ & $6.5-7.5$ & $4.0-7.5$ \\
\hline Silanol groups density $\left(\mathrm{SiOH} / \mathrm{nm}^{2}\right)$ & 2 to 4 & 2 to 3 & 8 to 10 & 4 to 8 \\
\hline Oil absorption $(\mathrm{cc} / 100 \mathrm{~g})$ & 150 to 250 & 80 to 120 & 50 to 250 & 150 to 250 \\
\hline $\mathrm{SiO}_{2}($ wt. $\%)$ & $>99[51]$ & & $\begin{array}{l}86 \text { to } 88 \text { and } 10 \text { to } \\
12 \text { of water [53] }\end{array}$ & \\
\hline
\end{tabular}

Table 2. Different types of commercial silicas.

\begin{tabular}{|c|c|c|c|c|c|}
\hline Silica references & Company & Silica type & $\begin{array}{l}\text { Surface area BET } \\
\left(\mathrm{m}^{2} / \mathrm{g}\right)\end{array}$ & $\begin{array}{l}\text { Reinforcing grade/ process } \\
\text { characteristic }\end{array}$ & Ref. \\
\hline Silene 732D & \multirow{6}{*}{ PPG } & \multirow{6}{*}{$\begin{array}{l}\text { Precipitated } \\
\text { silica }\end{array}$} & 33 & Low & \multirow{6}{*}[54]{} \\
\hline Hi-Sil 532EP & & & 55 & Low & \\
\hline Hi-Sil 315D & & & 125 & Medium & \\
\hline Hi-Sil 210 & & & 135 & Medium & \\
\hline Hi-Sil EZ $160 \mathrm{G}$ & & & 160 & High & \\
\hline Hi-Sil 134 G & & & 180 & High & \\
\hline Rubersil 250 & \multirow{4}{*}{ Glassven } & \multirow{4}{*}{$\begin{array}{l}\text { Precipitated } \\
\text { silica }\end{array}$} & $190-210$ & Ultra-high & \multirow{4}{*}[55]{} \\
\hline Rubersil 200 & & & $170-200$ & High & \\
\hline Rubersil 150 & & & $140-160$ & High & \\
\hline Rubersil 50 & & & $45-90$ & Medium & \\
\hline CAB-O-SIL® M-7D & \multirow{3}{*}{$\begin{array}{l}\text { CABOT } \\
\text { Corporation }\end{array}$} & \multirow{3}{*}{ Fumed silica } & Medium & High temperature vulcanized & \multirow{3}{*}[56]{} \\
\hline CAB-O-SIL® Duramold 2150 & & & \begin{tabular}{|l|} 
Medium-high \\
\end{tabular} & (HTV) silicone rubber & \\
\hline CAB-O-SIL $®$ Clarus ${ }^{\mathrm{TM}} 3160$ & & & High & $\begin{array}{l}\text { Liquid silicone rubber (LSR) } \\
\text { possess }\end{array}$ & \\
\hline Ultrasil@ $7000 \mathrm{GR}$ & \multirow{2}{*}{ Evonik } & \multirow{2}{*}{$\begin{array}{l}\text { Precipitated } \\
\text { silica }\end{array}$} & 170 & High & \multirow{2}{*}{\begin{tabular}{|l}
{$[50]$,} \\
{$[53]$}
\end{tabular}} \\
\hline Ultrasil@ $7000 \mathrm{GR}$ & & & 115 & High & \\
\hline Aerosil @ 90 & Evonik & Fumed silica & 90 & LSR & {$[52]$} \\
\hline Huberpol® 135 & HUBER & \begin{tabular}{|l|} 
Precipitated \\
silica
\end{tabular} & 150 & Medium & [57] \\
\hline
\end{tabular}

\section{RICE HUSK ASH (RHA)}

As mentioned in section 1, there are various methods to obtain silica from RH. Figure 2 summarize some of them. Combustion (thermal treatment) allows to produce amorphous RHA depending on the operational conditions, mainly the temperature achieved inside the reactor. Controlled combustion at reasonable equivalence ratios lead to oxidize the carbon and the hydrogen contained in the $\mathrm{RH}$ into $\mathrm{CO}_{2}$ and $\mathrm{H}_{2} \mathrm{O}$ [58]. The reactors commonly used for $\mathrm{RH}$ combustion are: fixed bed reactor, moving bed reactor and bubbling fluidized bed reactor (BFBR) [59]. This last technology seems to offer excellent conditions for thermochemical conversion of complex materials with irregular size and shape such as RH. Furthermore, BFBR is commonly used to transform materials with high ash content, low heat value and density [6], [36], [37]. All these characteristics are also typical for RH.
The RHA produced by combustion can be later treated (post-purification) with acid or alkaline substances to remove the inorganics contained ( $\mathrm{Zn}, \mathrm{K}, \mathrm{Na}, \mathrm{Mg}, \mathrm{Fe}, \mathrm{Ca}$, among others) and hence, to obtain higher $\mathrm{SiO}_{2}$ content. As reviewed by Soltani et al. [28], those post-purification routes to precipitate silica from RHA can be classified into three pathways. The first one starts with RHA solubilization in alkaline medium $(\mathrm{pH}>10)$ to form silicate solution (generally $\mathrm{Na}_{2} \mathrm{SiO}_{3}$ ) which allows the gel formation. Then, the silica gel is precipitated in acid medium to obtain a silica with $\mathrm{SiO}_{2}$ higher than 98wt.\%. Likewise, silica can be precipitated from the sodium silicate solution by adding $\mathrm{CO}_{2}$ and calcium. The second route is based on the silica extraction in an acid medium following by the addition of $\mathrm{Na}_{2} \mathrm{CO}$ and $\mathrm{CO}_{2}$. Finally, the third route is the dissolution of $\mathrm{RHA}$ in $\mathrm{NH}_{4} \mathrm{~F}$ to form $\left(\mathrm{NH}_{4}\right)_{2} \mathrm{SiF}_{6}$ which is later added to $\mathrm{NH}_{3}$ aqueous solution. 
In general terms, the RHA produced by combustion is composed mainly of silica around 75-97 wt.\% and other minerals such as $\mathrm{K}_{2} \mathrm{O}, \mathrm{Al}_{2} \mathrm{O}_{3}, \mathrm{CaO}, \mathrm{MgO}, \mathrm{Na}_{2} \mathrm{O}$ y $\mathrm{Fe}_{2} \mathrm{O}_{3}$. The RHA composition and structure not only depends on the region where $\mathrm{RH}$ is cultivated but also on the combustion temperature and reaction time.

In this sense, Martinez et al. [37] concluded that amorphous RHA is favored at temperature lower than $700^{\circ} \mathrm{C}$ which is in accordance with Rozaninee et al. [40] who expose that the minimum temperature for the onset of silica crystallization is around $700{ }^{\circ} \mathrm{C}$. Also, Chopra et al. [60] reported that the combustion of $\mathrm{RH}$ at temperature lower than $700{ }^{\circ} \mathrm{C}$ lead to amorphous silica into the RHA. According to Hamad et al. [61] RHA prepared at a temperature between 500 to $600{ }^{\circ} \mathrm{C}$ consists of amorphous silica, while cristobalite structure was detected at $800{ }^{\circ} \mathrm{C}$. Cristobalite and tridymite appeared after burning the $\mathrm{RH}$ at $1150{ }^{\circ} \mathrm{C}$. In the same way, Nehdi et al. [38] obtained amorphous silica from RHA (94 wt. $\% \mathrm{SiO}_{2}$ ) by using a BFBR (Torbed reactor) operated between 750 and $830{ }^{\circ} \mathrm{C}$. Table 3 shows different RHA compositions obtained by $\mathrm{RH}$ combustion, while while Table 4 shows some physicalchemical properties highlighting the type of reactor used. Besides chemical composition and structure, RHA surface chemistry is another important property for the application of this material in polymers. In general terms, RHA silica presents two main surface functional groups: silanol (Si-OH) and siloxane (-Si-O-Si-) [62].

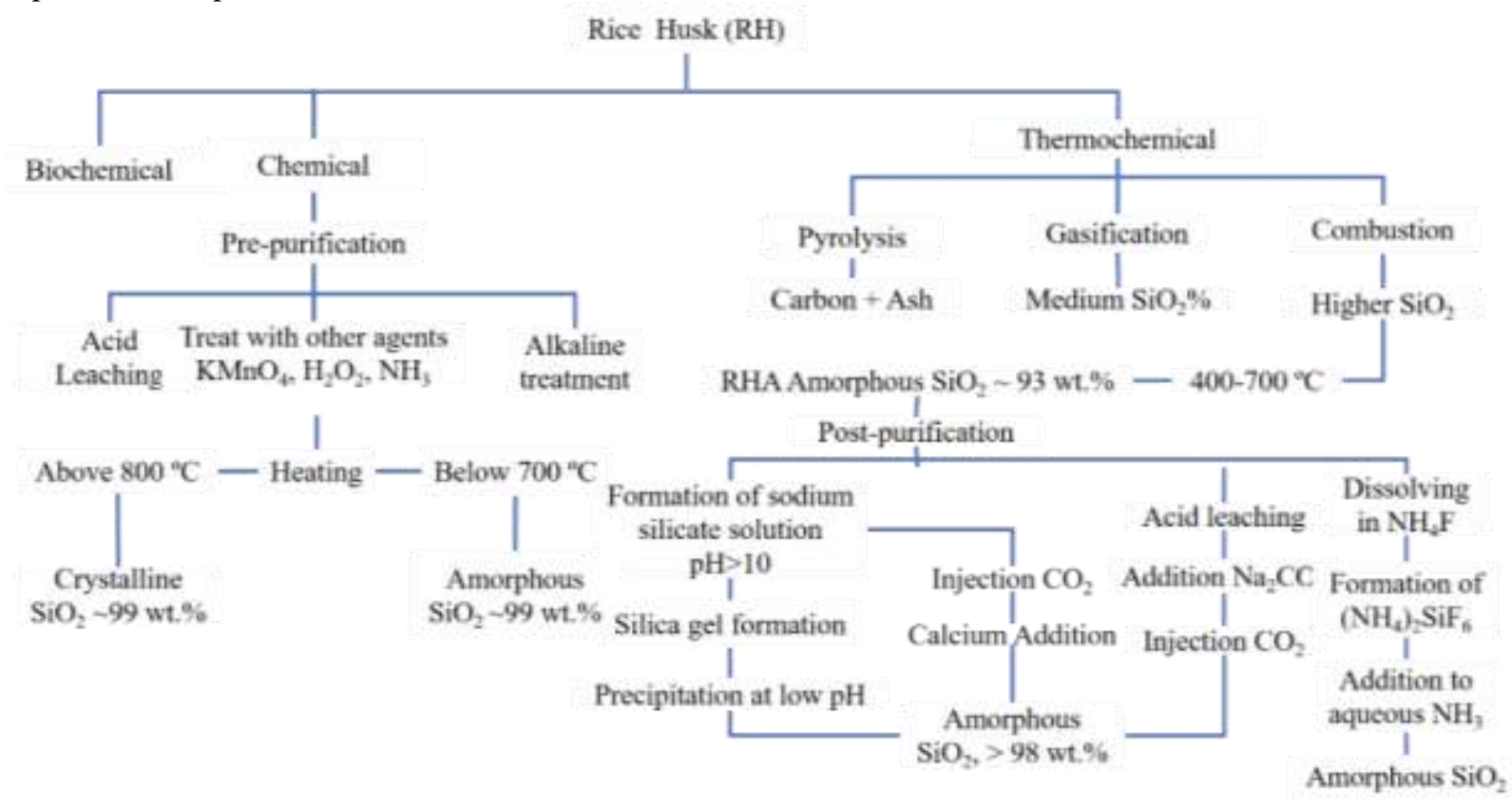

Figure 2. Different routes for producing silica from RH, (adapted from [28]).

These groups can be identified in the infrared spectra. The rocking vibration of $\mathrm{Si}-\mathrm{O}$ appears in a peak around $462 \mathrm{~cm}^{-1}$ while the asymmetric stretching and the symmetric stretching of Si-O-Si is near to $800 \mathrm{~cm}^{-1}$ and $1088 \mathrm{~cm}^{-1}$ respectively [77], [78]. In addition, Bakar et al. [39] reported infrared absorption peaks at $1044 \mathrm{~cm}-1$, $796 \mathrm{~cm}-1$ and $438 \mathrm{~cm}-1$ attributed to $\mathrm{SiO} 2$ stretching and bending vibrations. As observed in Table 1, Table 2 andTable 4, RHA as produced (without any post treatment), presents larger particle sizes and lower surface areas as compared with some commercial silicas. According to surface area parameter, RHA could be classified as low reinforcing filler.

\section{USE OF RHA AS REINFORCING FILLER IN POLYMERS}

Reinforced polymers with inorganic fillers have generated a huge academic and industrial interest because they modify important mechanical and physical properties such as tensile modulus, tensile strength, hardness and also the processability [79].

Among the common inorganic fillers used in thermoplastics and elastomers is found calcium carbonate, talc, clays (montmorillonite, kaolin), mica, silica and also alumina [80]. However, silica is the most widely used inorganic filler given among others, its low cost and its wide range of possibilities in construction and 
automobile industries as well as in many consumer goods and even in polymer applications. In this sense, there are many works on the RHA use as low cost filler [81]-[85] for elastomers (natural and synthetic rubber) and thermoplastics (polypropylene and high density polyethylene).

Table 3. RHA Composition obtained by combustion from diferent location reported in literature.

\begin{tabular}{|l|l|l|l|l|l|l|l|l|l|l|l|l|}
\hline $\mathbf{S i O}_{2}$ & $\mathbf{A l}_{2} \mathbf{O}_{3}$ & $\mathbf{F e}_{2} \mathbf{O}_{3}$ & $\mathbf{M g O}$ & $\mathbf{C a O}$ & $\mathbf{N a}_{2} \mathbf{O}$ & $\mathbf{K}_{2} \mathbf{O}$ & $\mathbf{P}_{2} \mathbf{O}_{5}$ & Others & Total & Location & Temp $\left({ }^{\circ} \mathbf{C}\right)$ & Ref. \\
\hline 98.0 & 0.5 & 0.1 & 0.1 & 0.2 & 0.1 & 0.4 & 0.1 & 0.5 & 100.0 & Spain & $400-600$ & {$[63]$} \\
\hline 97.6 & 0.1 & 0.0 & 0.0 & 0.0 & 0.1 & 0.2 & n.r & 2.3 & 100.3 & Malaysia & 700 & {$[64]$} \\
\hline 91.3 & 1.0 & 0.3 & 0.5 & 1.6 & n.r & 2.6 & 0.8 & 2.0 & 100.0 & China & 650 & {$[65]$} \\
\hline 84.3 & 0.3 & 0.6 & 0.5 & 1.4 & 0.4 & 0.2 & n.r & 12.2 & 99.9 & India & n.r & {$[66]$} \\
\hline 92.0 & 0.3 & 0.4 & 0.8 & n.r & 0.1 & 3.3 & 1.0 & 7.9 & 105.8 & n.r & n.r & {$[67]$} \\
\hline 91.6 & n.r & 0.2 & 0.5 & 1.6 & n.r & 0.4 & n.r & 5.7 & 100.0 & Nigeria & n.r & {$[68]$} \\
\hline 91.5 & 2.3 & 0.1 & 1.0 & n.r & 2.7 & 0.5 & n.r & 2.0 & 100.0 & Thailand & 650 & {$[69]$} \\
\hline 81.4 & 0.3 & 0.9 & 1.0 & 2.4 & 0.2 & 6.8 & n.r & 4.6 & 97.6 & China & 600 & {$[70]$} \\
\hline 81.1 & 0.1 & 0.1 & 0.8 & 1.1 & n.r & 1.4 & 3.2 & 10.4 & 98.1 & Italia & n.r & {$[71]$} \\
\hline 94.8 & 1.3 & 0.6 & 0.2 & 0.5 & 0.1 & 0.6 & 1.5 & 0.5 & 100.0 & China & 720 & {$[26]$} \\
\hline 91.4 & 0.8 & 0.1 & 0.0 & 3.2 & 0.2 & 3.7 & 0.4 & 0.1 & 100.0 & n.r & n.r & {$[72]$} \\
\hline 87.0 & 0.8 & 0.4 & 0.6 & 1.2 & 0.4 & 2.6 & n.r & 7.0 & 100.0 & Vietnam & $500-800$ & {$[73]$} \\
\hline 95.0 & 0.4 & 0.3 & 0.9 & 0.5 & 0.3 & 0.9 & 0.7 & 1.0 & 100.0 & Brazil & 700 & {$[27]$} \\
\hline 83.6 & 0.2 & 0.3 & 0.1 & 0.5 & 0.0 & 2.1 & 0.8 & 12.6 & 100.0 & Colombia & 750 & {$[37]$} \\
\hline 87.3 & 0.2 & 0.3 & 0.3 & 0.5 & 1.0 & 3.1 & n.r & 7.3 & 100.0 & n.r & 650 & {$[74]$} \\
\hline 94.6 & 0.3 & 0.3 & 0.3 & n.r & 0.2 & 1.3 & 0.3 & 2.7 & 100.0 & Egypt & 750 & {$[38]$} \\
\hline 95.8 & 0.0 & 0.1 & 0.4 & 0.7 & 1.3 & 0.6 & 0.5 & 0.7 & 100.0 & Malaysia & 600 & {$[39]$} \\
\hline 96.2 & traces & 0.1 & 0.4 & 0.1 & 0.1 & 1.6 & traces & n.r & 98.5 & Malaysia & n.r & {$[75][76]$} \\
\hline 96.7 & 0.1 & 0.0 & n.r & n.r & n.r & 0.7 & 0.2 & 0.1 & 97.8 & Brazil & 700 & \\
\hline 90.0 & 0.1 & 0.0 & n.r & 0.0 & n.r & 0.8 & 0.3 & 0.1 & 91.4 & Brazil & 840 & {$[6]$} \\
\hline 93.6 & 0.1 & 0.0 & n.r & n.r & n.r & 0.7 & 0.3 & 0.2 & 94.9 & Brazil & 700 & \\
\hline
\end{tabular}

n.r. not reported.

Table 4. Physics properties of RHA obtained by RH combustion in different reactors.

\begin{tabular}{|c|c|c|c|c|c|c|c|}
\hline \multirow{2}{*}{$\begin{array}{l}\text { Surface area } \\
\left(\mathrm{m}^{2} / \mathrm{g}\right)\end{array}$} & \multicolumn{3}{|c|}{ Particle size $(\mu \mathrm{m})$} & \multirow{2}{*}{$\begin{array}{l}\text { Molecular } \\
\text { structure }\end{array}$} & \multirow{2}{*}{ Type of reactor } & \multirow{2}{*}{ Temp. $\left({ }^{\circ} \mathrm{C}\right)$} & \multirow{2}{*}{ Ref. } \\
\hline & $\mathbf{d}_{10}$ & $\mathbf{d}_{50}$ & $\mathbf{d}_{90}$ & & & & \\
\hline 116 & n.r & \begin{tabular}{|l|}
$0.5-0.7$ \\
\end{tabular} & n.r & Amorphous & Mufle-type furnace & 600 & [39] \\
\hline 1.4 & n.r & 5.4 & n.r & n.r & n.r & n.r & {$[75],[76]$} \\
\hline 11.35 & 4.45 & 19.56 & 52.99 & Amorphous & FBR & 700 & {$[6]$} \\
\hline 39.27 & 4.87 & 19.74 & 35.39 & Crystalline & MG & 840 & {$[6]$} \\
\hline 26.74 & 10.4 & 41.58 & 78.32 & Amorphous & $\mathrm{S}$ & 700 & {$[6]$} \\
\hline n.r & n.r & n.r & n.r & Amorphous & \multirow{2}{*}{ Fixed bed } & $500-600$ & \multirow{2}{*}[61]{} \\
\hline n.r & n.r & n.r & n.r & Crystalline & & $800-1150$ & \\
\hline 17.96 & n.r & n.r & n.r & Amorphous & \multirow{2}{*}{ Torbed } & 750 & \multirow{2}{*}[38]{} \\
\hline 13.71 & n.r & n.r & n.r & Amorphous & & 830 & \\
\hline
\end{tabular}

n.r. not reported. MG: moving grate. S: suspension/entrained.

Particle size, surface activity and structure are important factors when evaluating a filler for polymer applications. High structure (OAN at or above $200 \mathrm{~mL} / 100 \mathrm{~g}$ [48]) is desirable for better processing, because homogeneous dispersion is achieved [86]. Additionally, fine primary particle size $(10-100 \mathrm{~nm})$ is desirable for high reinforcing degree [87]. Moreover, surface activity which indicates the chemical linkages between filler surface and polymer, is important to separate filler agglomerates during mixing process, thus providing better dispersion and avoiding the re-agglomeration. However, excessive polymer-filler bonding appears to be in principle highly undesirable, given the occurrence of a continuous rubber-filler network (prior to vulcanization) that hinders the process.
And if strong bonding takes place during vulcanization, the polymer would be completely immobilized at the filler surface and cause a drastic reduction in mobility [87].

Plastic composites prepared with nanoscale fillers (10$100 \mathrm{~nm}$ ) have yielded greatest increases in mechanical properties compared with micron-sized fillers, mainly due to its larger surface area [88]. Also, it is well known that the addition of surface modifiers or compatibilizers (also known as coupling agents such as Aerosil r816: Aerosil 200 functionalizing with hexadecylsilane, 3APE: 3- aminopropyl triethoxysilane, methacryloxymethyltri- ethoxysilane, PP-g-maleic 
anhydride, PP-g-acrylic acid (3-acryloxypropyl) methyldimethoxysilane, among others) into polymer composites have the ability to form a stable bond between organic (polymer) and inorganic (filler) materials [89] which hence improve the surface activity.

There are different methods for the incorporation of micro and nanoscale particles into polymer. The most used method is melt blending or melt mixing. The melt blending process involves the dispersion of fillers into a polymer melt using well-known melt processing techniques (e.g. extrusion and compression molding) of polymers. In this method, the polymer is directly mixed with the filler in the molten state and no solvent is required [90].

\subsection{Polymer- filler interaction}

The filler-polymer interaction can occur by physical or chemical way. The physical interaction is mainly governed by the adsorption of the polymer free radicals onto the filler porous surface. On the other hand, the chemical interaction is governed by the chemical surface of the filler (which is assessed by the surface functional groups) and its reaction with the polymer free radicals [94]. However, some authors have noticed that is not enough the surface chemistry to achieve a good interaction. For that reason, they suggest the addition of coupling agent, for instance an organosilane such as $\alpha$ mercaptopropyltrimetoxysilane [56], [95] or the use of compatibilized composites such as PP-g-maleic anhydride, PP-g-acrylic acid and HDPE-g-maleic anhydride [93] required for enhance the dispersion, adhesion and polymer-filler compatibility.

The organosilane consists of a silica based compound with an organic molecule (R) in three bonds of the $\mathrm{Si}$ atom and a functional group (X) on the other side (represented as X-Si-(R) $\left.{ }_{3}[91]\right)$. According to Fuad et al. [92] the polymer-filler interaction with the use of organosilane occurs in three steps. First, it is the formation of organosilanol by the hydrolysis of the organosilane with the water adsorbed onto the filler surface. Second, occurs the interaction between organosilanol and the hydroxyl onto the filler surface by hydrogen bond. Finally, a condensation reaction (by water elimination) takes place to form the Si-O crosslinks between the filler surface and the functional groups from the organosilane.

\subsection{RHA /thermoplastic composites}

As commented above, extensive studies have been carried out about the use of RHA as reinforcing filler material, mainly in polyolefins such as polyethylene (PE) and polypropylene (PP). Ingeneral, the RHA addition into thermoplastics causes an increase in the tensile modulus and a decrease in the tensile strength and elongation at break as compared with the matrix without filler [84], [85], [93]. That behavior disagrees with the commercial silica performance because all three properties increase compared with no filled composites as shown in Table 5. That phenomenon is attributed to the poor filler-polymer compatibility in RHA composites.

For instance, Fuad et al. [84] introduce white rice husk ash (WRHA) and black rice husk ash (BRHA) as a reinforcing filler into PP matrix. WRHA and BRHA contained approximately $96 \mathrm{wt} . \%$ and $54 \mathrm{wt} . \%$ of silica, respectively. Both types of fillers exhibited an enhancement of flexural modulus at expenses of tensile strength when the filler amount increase. Even though, the flexural modulus of BRHA-PP was higher than WRHA-PP composites.

Ayswarya et al. [93] also studied the RHA effect on the mechanical properties of high density polyethylene (HDPE) as well as the influence of the HDPE compatibilization with maleic anhydride (HDPE-MA). In that research, the increase of different RHA (obtained in a furnace at $550^{\circ} \mathrm{C}$ ) from $1.0 \mathrm{wt} . \%$ to $2.5 \mathrm{wt} . \%$ into uncompatibilized HDPE, showed a decrease steadily in tensile strength and elongation at break. The same phenomenon was observed in RHA/PP composites [84], [85]. The decrease of these two properties is attributed to the polymer-filler incompatibility [84], [85], [93]. However, the use of HDPE-MA improves the polymerfiller compatibility. The maleic anhydride is bonded to the HDPE and become a bridge between filler silanol group and polymer which leads to enhance the fillerpolymer compatibility [93]. The HDPE-MA filled with RHA in Ayswarya et al. [93] research work showed an increase in tensile strength and elongation at break with the increase of RHA up to 1.5 wt.\%. Both HDPE-RHA and HDPE-MA-RHA blends showed an increase in the tensile modulus with the RHA loading increase as is shown in Table 5. That increase in tensile modulus is in accordance with some research works [84], [85]. In this regard, Ismail et al. [85] observed that the increase of RHA (mean particle size $5.4 \mu \mathrm{m}$; surface area $1.4 \mathrm{~m}^{2} / \mathrm{g}$ and density $2.2 \mathrm{~g} / \mathrm{m}^{3}$ ) filled in natural rubber-linear low density polyethylene (NR-LDPE) blends showed an increase in tensile modulus of composites which means higher stiffness. Similarly, Fuad et al. [84] noticed an increase in flexural modulus in PP-RHA blend when the filler increase from 0 to $40 \mathrm{wt} . \%$.

Melt flow measurement is another important property for polymer-RHA composites. As some researchers have showed, melt flow index (MFI) decreases with the increase of filler content [92], [93], because the polymer 
mobility restriction caused by the filler addition into polymer, which is the same phenomenon with the tensile modulus [94]. Low MFI indicates a higher melt viscosity and higher stiffness which means a high reinforcing grade.

On the other hand, Siriwardena et al. [95] evaluated the effect of incorporate RHA into ethylene-propylenediene-terpolymer/polypropylene (EPD/PP) blends on physical properties of the final polymer. They noticed that RHA incorporation increased composite density which has an influence on water absorption behavior. That effect makes more difficult the water molecules penetration into the composite. They also compared the EPD/PP-RHA composites with the EPD/PP filled with commercial silica (with higher surface area and more -
$\mathrm{OH}$ groups than RHA) and observed higher water absorption in the commercial silica composites which is not generally desired for industrial applications.

Regarding molecular structure type effect (amorphous or crystalline) on the reinforced compound, in general terms amorphous RHA presents better reinforcing capacity than crystalline because the high reactivity [84], [96]. Fuad et al. [84] compared the effect of amorphous and crystalline RHA addition into PP on mechanical properties. The composites showed lower flexural modulus and slightly lower tensile strength when 40 $\%$ wt. of crystalline WRHA was used instead of BRHA (amorphous) at same load which is attributed to the higher reactivity of the amorphous fillers.

Table 5. Mechanical properties for common thermoplastics with RHA and silica as fillers.

\begin{tabular}{|c|c|c|c|c|c|c|}
\hline Matrix & Filler & $\begin{array}{l}\text { RHA load } \\
\text { (wt.\%) }\end{array}$ & $\begin{array}{l}\text { Tensile strength } \\
\text { at break (MPa) }\end{array}$ & $\begin{array}{l}\text { Tensile/ Flexural } \\
\text { modulus (MPa) }\end{array}$ & $\begin{array}{l}\text { Elongation at } \\
\text { break }(\%)\end{array}$ & Ref. \\
\hline \multirow{4}{*}{ HDPE } & Without filler & 0 & 20 & $240^{\mathrm{a}}$ & 16 & \multirow{8}{*}[93]{} \\
\hline & \multirow{7}{*}{$\begin{array}{l}\text { RHA obtain by combustion } \\
\left(550^{\circ} \mathrm{C}\right), 64.8 \text { wt. } \% \mathrm{SiO}_{2}\end{array}$} & 1.0 & 19 & $260^{\mathrm{a}}$ & 14 & \\
\hline & & 1.5 & 18.0 & $275^{\mathrm{a}}$ & 14 & \\
\hline & & 2.5 & 17 & $305^{\mathrm{a}}$ & 13 & \\
\hline \multirow{4}{*}{ HDPE-MA } & & 0 & 22 & $245^{\mathrm{a}}$ & 15 & \\
\hline & & 1.0 & 26 & $270^{\mathrm{a}}$ & 25 & \\
\hline & & 1.5 & 27.0 & $285^{\mathrm{a}}$ & 28 & \\
\hline & & 2.5 & 26.0 & $325^{\mathrm{a}}$ & 18 & \\
\hline \multirow{4}{*}{ LDPE } & Without filler & 0 & 19.8 & $199^{\mathrm{a}}$ & 1439 & \multirow{4}{*}[97]{} \\
\hline & Aerosil 90 & \multirow{3}{*}{2} & 22.6 & $262^{\mathrm{a}}$ & 1625 & \\
\hline & Aerosil 200 & & 22.3 & $274^{\mathrm{a}}$ & 1613 & \\
\hline & Aerosil r816 & & 22.8 & $275^{\mathrm{a}}$ & 1738 & \\
\hline \multirow{2}{*}{ PP } & Without filler & 0 & 24.3 & $1202^{\mathrm{a}}$ & 3.4 & \multirow{2}{*}{ [98] } \\
\hline & $\mathrm{SiO}_{2},\left(\right.$ Aldrich $180 \mathrm{~m}^{2} / \mathrm{g}, 99.5$ wt.\%) & 5 & 30.4 & $1486^{\mathrm{a}}$ & 7.8 & \\
\hline \multirow{2}{*}{ PP } & Without filler & 0 & 37.0 & $1400^{\mathrm{a}}$ & 80 & \multirow{2}{*}[99]{} \\
\hline & Precipitated nano-SiO ${ }_{2}$ & $1.5^{\mathrm{c}}$ & 37.3 & $1700^{\mathrm{a}}$ & 230 & \\
\hline \multirow{5}{*}{$\mathrm{PP}$} & Without filler & 0 & 26.3 & $1579^{\mathrm{b}}$ & $>600$ & \multirow{5}{*}[84]{} \\
\hline & WRHA crystalline silica with & 20 & 22.5 & $1936^{\mathrm{b}}$ & 127 & \\
\hline & 96.20 wt. $\% \mathrm{SiO}_{2}$ and $1.4 \mathrm{~m}^{2} / \mathrm{g}$ & 40 & 19.1 & $2544^{\mathrm{b}}$ & 22.1 & \\
\hline & \multirow{2}{*}{$\begin{array}{l}\text { BRHA amorphous silica with } \\
53.88 \text { wt. } \% \mathrm{SiO}_{2} \text { and } 26.8 \mathrm{~m}^{2} / \mathrm{g}\end{array}$} & 20 & 23.8 & $2306^{\mathrm{b}}$ & 11.2 & \\
\hline & & 40 & 22.1 & $3124^{\mathrm{b}}$ & 1.7 & \\
\hline \multirow{4}{*}{$\mathrm{PP}$} & Without filler & 0 & \multirow{4}{*}{ n.r } & $900^{\mathrm{a}}$ & 740 & \multirow{4}{*}[100]{} \\
\hline & \multirow{3}{*}{$\begin{array}{l}\text { Milled RHA (1-10 } \mu \mathrm{m} \text { size of } \\
\text { particles/ aggregates) }\end{array}$} & 4 & & $980^{\mathrm{a}}$ & 750 & \\
\hline & & 10 & & $1350^{\mathrm{a}}$ & 700 & \\
\hline & & 19 & & $1480^{\mathrm{a}}$ & 520 & \\
\hline \multirow{5}{*}{$\begin{array}{l}\text { PP/NR } \\
(7: 3)\end{array}$} & Without filler & 0 & 13 & $250^{\mathrm{a}}$ & 175 & \multirow{5}{*}[85]{} \\
\hline & RHA with $14 \mathrm{~m}^{2} / \mathrm{g}$ & 30 & 10.5 & $360^{\mathrm{a}}$ & 90 & \\
\hline & RHA with $1.4 \mathrm{~m}^{2} / \mathrm{g}$ & 60 & 9.0 & $380^{\mathrm{a}}$ & 53 & \\
\hline & \multirow{2}{*}{$\begin{array}{l}\text { RHA with } 1.4 \mathrm{~m}^{2} / \mathrm{g} \text { compatibilized } \\
\text { with } 3 \text {-APE }\end{array}$} & 30 & 11.5 & $470^{\mathrm{a}}$ & 60 & \\
\hline & & 60 & 10.5 & $510^{\mathrm{a}}$ & 40 & \\
\hline
\end{tabular}

a: tensile modulus; b: flexural modulus; c: in vol.\%; n.r. not reported; PP: polypropylene; HDPE: high density polyethylene; HDPEMA: compatibilized with maleic anhydride; LDPE: low density polyethylene; Aerosil r816: Aerosil 200 functionalizing with hexadecylsilane; 3-APE: 3- aminopropyl triethoxysilane.

\subsection{RHA /elastomers composites}

The effect of a filler on the rubber properties can be mainly related to: i) how many polymer chains are attached to the filler surface and ii) how strongly they are attached. The characteristics of a filler such as particle 
size, surface area, molecular structure and surface activity have an important role in the polymer-filler interaction. As shown in section 3, RHA presents relatively larger particle/aggregate size and lower specific surface area than commercial silica, but even so, similar molecular structure and chemical composition. Therefore, RHA seems to be attractive for polymer industry applications.

Many researchers have been studying the use of RHA as filler in natural and/or synthetic rubber [81]-[83], [101], [102]. Overall results indicate that RHA can be used as a cheap filler for natural rubber materials where high quality mechanical properties are not required.

The common trend in the mechanical properties is the increase in tensile strength, tensile modulus at 300\%, tensile strain and hardness, when the RHA amount increase up to $30 \mathrm{phr}$, as is shown in Table 6 .

For instance, Costa et al. [101] reported that the tensile strength of milled RHA/NR vulcanized composites increase with the increasing filler content until a maximum level reached at $20 \mathrm{phr}$. The reduction of this property at higher loads may be caused by filler particles agglomeration that leads to poor polymer-filler compatibility.

In general terms, commercial silica provide better mechanical properties than the RHA, mostly due to their high surface area (small particle size) and surface activity [103]. However, chemical treatments applied to RHA enhance the performance of RHA-rubber composites.

For instance, Da Costa et al. [101], showed a treatment with 20 wt. $\% \mathrm{NaOH}$ and $12 \mathrm{M} \mathrm{HCl}$ in order to improve the mechanical properties of NR filled with RHA. As a result, the composites filled at $20 \mathrm{phr}$ with treated RHA showed a higher tensile strength as compared with the NR filled at $20 \mathrm{phr}$ with commercial silica (Zeol-175), and even higher than the Zeol-175/NR composite compatibilized with Si-69 [101].

Table 6. Mechanical properties for common elastomers with RHA and silica as fillers.

\begin{tabular}{|c|c|c|c|c|c|c|c|c|c|c|c|c|}
\hline \multirow[b]{2}{*}{ Matrix } & \multicolumn{6}{|l|}{ Filler } & \multirow{2}{*}{$\begin{array}{l}\text { Filler } \\
\text { load } \\
\text { (phr) }\end{array}$} & \multirow{2}{*}{$\begin{array}{l}\text { Tensile } \\
\text { strength } \\
\text { at break } \\
\text { (MPa) }\end{array}$} & \multirow{2}{*}{$\begin{array}{l}\text { Tensile } \\
\text { modulus } \\
\text { at 300\% } \\
\text { (MPa) }\end{array}$} & \multirow{2}{*}{$\begin{array}{l}\text { Tensile } \\
\text { strain } \\
\text { at } \\
\text { break } \\
(\%)\end{array}$} & \multirow[b]{2}{*}{$\begin{array}{l}\text { Hard- } \\
\text { ness }\end{array}$} & \multirow[b]{2}{*}{ Ref. } \\
\hline & Type & $\begin{array}{l}\mathrm{SiO}_{2} \\
\text { (wt.\%) }\end{array}$ & \begin{tabular}{|l} 
LOI \\
(wt.\%)
\end{tabular} & $\begin{array}{l}S_{\text {BET }} \\
\left(\mathbf{m}^{2} / \mathbf{g}\right)\end{array}$ & $\begin{array}{l}\text { Particle } \\
\text { size } \\
(\mu \mathrm{m})\end{array}$ & $\begin{array}{l}\text { Coupling } \\
\text { agent }\end{array}$ & & & & & & \\
\hline \multirow{9}{*}{ NR } & \multicolumn{6}{|l|}{ Without filler } & 0 & 11 & 2.2 & 780 & 37 & \multirow{9}{*}[101]{} \\
\hline & \multirow{2}{*}{ RHA } & \multirow{4}{*}{42} & \multirow{4}{*}{25} & \multirow{4}{*}{109} & \multirow{4}{*}{2.9} & \multirow[b]{2}{*}{ no } & 20 & 16 & 3.2 & 555 & 39 & \\
\hline & & & & & & & \begin{tabular}{|l|}
40 \\
\end{tabular} & 11 & 4.3 & 526 & 41 & \\
\hline & \multirow{2}{*}{ RHA } & & & & & $\mathrm{Si} 60$ & 20 & 18 & 3.6 & 585 & 40 & \\
\hline & & & & & & S1-69 & 40 & 12 & 4.9 & 492 & 43 & \\
\hline & \multirow{2}{*}{ TRHA } & \multirow{2}{*}{36.2} & \multirow{2}{*}{49.2} & \multirow{2}{*}{12} & \multirow{2}{*}{5.5} & \multirow{2}{*}{ no } & 20 & 26 & 4.5 & 617 & 41 & \\
\hline & & & & & & & 30 & 12.5 & 4.8 & 600 & 43 & \\
\hline & \multirow{2}{*}{ Silica Zeol-175 } & & & & & no & \multirow{2}{*}{20} & 20 & 6.5 & 615 & 45 & \\
\hline & & & & 185 & 0.018 & \begin{tabular}{|l|} 
Si-69 \\
\end{tabular} & & 21 & 4.8 & 642 & 44 & \\
\hline \multirow{7}{*}{ NR } & \multicolumn{6}{|l|}{ Without filler } & 0 & 19.5 & 3.5 & 900 & 35 & \multirow{7}{*}[83]{} \\
\hline & \multirow{2}{*}{ WRHA } & \multirow{2}{*}{77} & \multirow{2}{*}{2.3} & & 22 & & 20 & 22.7 & 6.8 & 755 & 39 & \\
\hline & & & & 17 & 2.2 & no & 40 & 18.7 & 8.4 & 690 & 45 & \\
\hline & & & & & & & 20 & 20.2 & 6 & 820 & 38 & \\
\hline & BRHA & 42 & 25 & 109 & 2.9 & no & 40 & 17.5 & 7 & 720 & 43 & \\
\hline & Silica Zeol-175 & & & 185 & 0018 & & 20 & 23.5 & 7.8 & 750 & 42 & \\
\hline & Silica Zeol-1/5 & & & 185 & 0.018 & no & 40 & 20.9 & 10.5 & 620 & 50 & \\
\hline & & & & & & & 0 & 15 & 1.99 & 742 & 42 & \\
\hline NR & WRHA & & & 1.4 & 5.4 & no & \begin{tabular}{|l|}
10 \\
\end{tabular} & \begin{tabular}{|l|}
17.1 \\
\end{tabular} & 2.01 & 717 & 44 & {$[102]$} \\
\hline & & & & & & & 20 & 16.4 & 2.15 & 697 & 47 & \\
\hline
\end{tabular}

n.r. not reported; Si-69: bis(3-triethoxysilylpropyl)-tetrasulfane; LOI: loss on ignition, TRHA: RHA treated with 20 wt.\% NaOH and $12 \mathrm{M} \mathrm{HCl}$.

In the same way, Ismail et al. [79] also found an increase of the tensile strenght as WRHA increased, until a maximun of $10 \mathrm{phr}$. This behavior is in accordance with Costa et al. [101] which is attributed to the possible particles agglomeration, as commented above.
In other work, Costa et al. [82] evaluated the vulcanization process of NR filled with BRHA (75 wt.\% $\mathrm{SiO}_{2}, 21$ wt.\% LOI, $17 \mathrm{~m}^{2} / \mathrm{g}$ ) and WRHA (97 wt.\% $\mathrm{SiO}_{2}$, 0.2 wt.\% LOI, $\left.109 \mathrm{~m}^{2} / \mathrm{g}\right)$. They reported that the vulcanization process was accelerated in the presence of WRHA, whereas the BRHA filler did not present a 
significant effect. The WRHA/NR compounds showed a remarkable increase in vulcanization rate constant as compared to the NR filled with BRHA or commercial silica (Zeosil-175). The higher vulcanization rate is found for BRHA/NR as compared with that reported for Zeosil$175 / \mathrm{NR}$ at the same loads (above $20 \mathrm{phr}$ ). This fact was attributed to differences in filler properties, such as surface area, surface activity, $\mathrm{pH}$, particle size, moisture content, and metal content. Furthermore, the $\mathrm{ZnO}$ added to the composites may led to accelerate the vulcanization process [81], [82].

In the case of partial replacement of commercial silica by RHA, Costa et al [79] found that when Zeolsil-175 is partially replacement by WRHA, the composites showed a catalitic effect given the aceleration of the vulcanization. As mentioned before, this fact is attributed to filler properties. Authors attributed the WRHA catalitic efect mainly to the presense of metal impurities such as $\mathrm{K}, \mathrm{Na}, \mathrm{Ca}, \mathrm{Mg}, \mathrm{Fe}, \mathrm{P}$ and $\mathrm{Al}$, which exist in the form of oxides or silicates.

In addition, the surface chemistry, represented by the silanol groups, also shows an effect on the vulcanization process. Hydroxyl groups on silica surface could form very strong intermolecular hydrogen bonds with another hydroxyl of an adjacent silica particle. This hydrogen bonds causes the easily formation of tightly held aggregates which cause a poor dispersion of silica particles in a rubber matrix [81], [104], [105]. The hydrogen bonds also contributes to increase viscosity of WRHA/NR composite faster than most fillers specially those with high surface are. The vulcanization additives could be absorbed on silica surface cousing longer scorch time and reduces the state of cure [81].

Other kind of elastomers or elastomer blends have been investigated with RHA as filler, such as styrene butadiene rubber (SBR) [86], epoxidized rubber [75], $\mathrm{NR} /$ ethylenepropylene-diene monomer (EPDM) blends [106], [107], polysiloxane elastomers [108], among others.

\section{CONCLUSIONS}

Most of researchers coincide that the RHA addition into a thermoplastic matrix increases elastic modulus and decreases steadily tensile strength and elongation at break. This phenomenon is attributed to the poor polymer-filler interaction.

That loosely interaction can be enhanced with the use of intermediate compounds that leads to link the filler to the polymer chain (coupling agents). Commonly used compounds are silanes and maleic anhydride.
In addition, the amorphous molecular structure filler is desired for better reinforcing applications due to the high reactivity compared with crystalline structure. This high reactivity leads to enhance the filler-polymer interaction as well.

The surface chemistry (represented by the silanol groups) influences the composite performance from the processing point of view. That fact is attributed to the hydrogen bond formation between hydroxyl groups of adjacent particles, causing a poor dispersion. In addition, hydroxyl groups become hydrophilic the reinforced composites.

\section{ACKNOWLEDGMENTS}

The authors would like to express all their gratitude to COLCIENCIAS for the financial support given by the research project (FP44842-026-2016-2002). N. CardonaUribe is in debt with the Integrated Center for the Development of Research (CIDI) at Pontificia Bolivariana University and its program "Formación Investigativa" for the MSc scholarship.

\section{REFERENCES}

[1]FAOSTAT, “Cultivos," 2017. [Online]. Available:https://goo.gl/h8SdbK.

[2] FAO, "Rice market monitor," vol. XX, no. 1, p. 38, 2017.

[3] FAO, "Rice market monitor," vol. XX, no. 3, pp. 32,2017 .

[4] DANE, "4 Censo Nacional Arrocero," Bogotá D.C,2017.

[5]J. Varón Cemargo, “Diseño, construcción y puesta a punto de un prototipo de quemador para la combustión continua y eficiente de la cascarilla de arroz," El Hombre y la Máquina, no. 25, pp. 128-135, 2005.

[6] I. J. Fernandes, D. Calheiro, A. G. Kieling, C. A. M.M. Moraes, T. L. A. C. A. C. Rocha, F. A. Brehm, and R. C. E. E. Modolo, "Characterization of rice husk ash produced using different biomass combustion techniques for energy," Fuel, vol. 165, pp. 351-359, Feb. 2016.

[7]J. S. Lim, Z. Abdul Manan, S. R. Wan Alwi, and H. Hashim, "A review on utilisation of biomass from rice industry as a source of renewable energy," Renew. Sustain. Energy Rev., vol. 16, no. 5, pp. 3084-3094, 2012. 
[8] K. G. Mansaray and A. E. Ghaly, "Thermal degradation of rice husks in nitrogen atmosphere," Bioresour. Technol., vol. 65, pp. 13-20, 1998.

[9] M. J. Antal, S. G. Allen, X. Dai, B. Shimizu, M. S. Tam, and M. Grønli, "Attainment of the theoretical yield of carbon from biomass," Ind. Eng. Chem. Res., vol. 39, pp. 4024-4031, 2000.

[10]P. T. Williams and N. Nugranad, "Comparison of products from the pyrolysis and catalytic pyrolysis of rice husks," Energy, vol. 25, pp. 493-513, 2000.

[11]D. Quiceno and M. Mosquera, "Alternativas tecnológicas para el uso de la cascarilla de arroz como combustible," Universidad Autónoma de Oriente, Santiago de Cali, 2010.

[12]M. Pizano, "Sustratos," in Floricultura y Medio Ambiente. Producción de Flores sin Bromuro de Metilo, PNUMA, Ed. 2001, pp. 81-92.

[13]FAO y Ministerio de Agricultura y Ganadería, "Elaboración y uso del bocashi," El Salvador: FAO, 2011, p. 12.

[14]M. R. . Gidde and A. P. Jivani, "Waste to wealth potential of rice husk in India a literature review," Proc. Int. Conf. Clean. Technol. Environ. Manag., pp. 586590, 2007.

[15]L. N. Lacayo, "Cascarilla de arroz como suplemento alimenticio," LA PRENSA. Jul-2001.

[16]K. R. Bhattacharya and S. Zakiuddin Ali, "Rice Husk and its utilisation," in Introduction to Rice-grain Technology, New Delhi: Woodjead Publishing India Pvt. Ltd, 2015, pp. 246-264.

[17]D. F. Hidalgo, "Más ganancias en cerdos con aserrín y cascarilla de arroz.," La Patría. Manizales-Colombia, 2013.

[18]World Society for Animal Protection (WSPA), "Los beneficios de la cama profunda generan bienestar a los cerdos y sostenibilidad económica y ambiental." Ubaque-Colombia, p. 4, 2010.

[19]V. F. Perdomo, "Laminas De Aglomerado De Cascarilla De Arroz," Incubar Huila. Huila-Colombia, 2010.

[20]S. L. Lim, T. Y. Wu, E. Y. S. Sim, P. N. Lim, and C. Clarke, "Biotransformation of rice husk into organic fertilizer through vermicomposting," Ecol. Eng., vol. 41, pp. 60-64, 2012.

[21]R. Pode, B. Diouf, and G. Pode, "Sustainable rural electrification using rice husk biomass energy: a case study of Cambodia," Renew. Sustain. Energy Rev., vol. 44, pp. 530-542, 2015.

[22]F. Vitali, S. Parmigiani, M. Vaccari, and C. Collivignarelli, "Agricultural waste as household fuel: Techno-economic assessment of a new rice-husk cookstove for developing countries," Waste Manag., vol. 33, pp. 2762-2770, 2013.

[23]O. Garcia, M. Hernandez, J. Gonzalez, and H. J. Pava, "Formulación y evaluación del programa de producción más limpia en arroz Diana del Tolima," Universidad de la Sabana. 2009.

[24]M. Martínez B, "Silicio," in Materiales y materias primas, 2011.

[25]T. Madhiyanon, A. Lapirattanakun, P. Sathitruangsak, and S. Soponronnarit, "A novel cyclonic fluidized-bed combustor ( $\psi$-FBC): Combustion and thermal efficiency, temperature distributions, combustion intensity, and emission of pollutants," Combust. Flame, vol. 146, no. 1-2, pp. 232-245, Jul. 2006.

[26]G. Chen, G. Du, W. Ma, B. Yan, Z. Wang, and W. Gao, "Production of amorphous rice husk ash in a $500 \mathrm{~kW}$ fluidized bed combustor," Fuel, vol. 144, pp. 214-221, Mar. 2015.

[27]L. Armesto, A. Bahillo, K. Veijonen, A. Cabanillas, and J. Otero, "Combustion behaviour of rice husk in a bubbling fluidised bed," Biomass and Bioenergy, vol. 23, no. 3, pp. 171-179, Sep. 2002.

[28]N. Soltani, A. Bahrami, M. I. Pech-Canul, and L. A. González, "Review on the physicochemical treatments of rice husk for production of advanced materials," Chem. Eng. J., vol. 264, pp. 899-935, 2015.

[29]D. G. Nair, A. Fraaij, a. a K. Klaassen, and a. P. M. Kentgens, "A structural investigation relating to the pozzolanic activity of rice husk ashes," Cem. Concr. Res., vol. 38, pp. 861-869, 2008.

[30]R. L. Day, "Pozzolans for use in low-cost Housing," Ottawa: International Development Research Centre, 1990, pp. 8-104.

[31]Asia BioBusiness Pte Ltd, "Potential World Markets for Innovative Rice Businesses in Thailand Final 
Report," in Intellectual Property, Singapore, 2006, pp. 433.

[32]F. Cerezo, "Goodyear usará cáscara de arroz para hacer ruedas," EL MUNDO. Madrid, 2014.

[33]L. Sun and K. Gong, "Silicon-Based materials from rice husks and their applications," Ind. Eng. Chem. Res., vol. 40, pp. 5861-5877, 2001.

[34]H. S. Kim, H. S. Yang, H. J. Kim, and H. J. Park, "Thermogravimetric analysis of rice husk flour filled thermoplastic polymer composites," J. Therm. Anal. Calorim., vol. 76, no. 2, pp. 395-404, 2004.

[35]A. P. Vasco and M. V Betancur, "Estudio de la cinética de adsorción de índigo carmín en piezas abrasivas," Rev. Investig. Apl., vol. 8, pp. 131-139, 2014.

[36]R. Saidur, E. a. Abdelaziz, A. Demirbas, M. S. Hossain, and S. Mekhilef, "A review on biomass as a fuel for boilers," Renew. Sustain. Energy Rev., vol. 15, pp. 2262-2289, 2011.

[37]J. D. Martínez, T. Pineda, J. P. López, and M. Betancur, "Assessment of the rice husk lean-combustion in a bubbling fluidized bed for the production of amorphous silica-rich ash," Energy, vol. 36, no. 6, pp. 3846-3854, 2011.

[38]M. Nehdi, J. Duquette, and A. El Damatty, "Performance of rice husk ash produced using a new technology as a mineral admixture in concrete," Cem. Concr. Res., vol. 33, no. 8, pp. 1203-1210, Aug. 2003.

[39]R. A. Bakar, R. Yahya, and S. N. Gan, "Production of High Purity Amorphous Silica from Rice Husk," Procedia Chem., vol. 19, pp. 189-195, 2016.

[40]M. Rozainee, S. P. Ngo, A. A. Salema, and K. G. Tan, "Fluidized bed combustion of rice husk to produce amorphous siliceous ash," Energy Sustain. Dev., vol. 12, no. 1, pp. 33-42, 2008.

[41]I. Valchev, V. Lasheva, T. Tzolov, and N. Josifov, "Silica Products From Rice Hulls," J. Univ. Chem. Technol. Metall., vol. 44, no. 3, pp. 257-261, 2009.

[42]K. Rohatgi, S. V Prasad, and P. K. Rohatgi, "Release of silica-rich particles from rice husk by microbial fermentation," J. Mater. Sci. Lett., vol. 6, no. 7, pp. 829831, 1987.

[43]S. K. Wason, "Synthetic silicas," in Handbook of fillers for plastics, Springer Science \& Business Media,
1987, pp. 165-180.

[44]E. F. Vansant, P. Van Der Voort, and K. C. Vrancken, "Chapter 1 Silica: preparation and properties," Stud. Surf. Sci. Catal., vol. 93, pp. 3-30, 1995.

[45]O. W. Flörke, H. A. Graetsch, F. Brunk, L. Benda, S. Paschen, H. E. Bergna, W. O. Roberts, W. A. Welsh, C. Libanati, M. Ettlinger, D. Kerner, M. Maier, W. Meon, R. Schmoll, H. Gies, and D. Schiffmann, "Silica," in Ullmann's Encyclopedia of Industrial Chemistry, WileyVCH Verlag GmbH \& Co. KGaA, 2000, pp. 421-507.

[46]W. A. Patrick, "Silica gel and process of making same.," US1297724 A, 18-Mar-1919.

[47]P. A. Ciullo, Industrial minerals and their uses: a handbook and formulary. William Andrew, 1996.

[48]P. A. Ciullo, N. Hewitt, P. A. Ciullo, and N. Hewitt, "COMPOUNDING MATERIALS," in The Rubber Formulary, Elsevier, 1999, pp. 4-49.

[49]I. Franta, "CHAPTER 5 - Reclaimed rubbers," in Studies in Polymer Science, vol. 1, 1989, pp. 300-324.

[50]Evonik Industries AG, "A + Outperforming the standards. Reinforzing filler for Rubber industry," 2016.

[51]Wacker Chemie AG, "HDK® PYROGENIC SILICA," 2017. [Online]. Available: www.wacker.com. [Accessed: 20-Apr-2017].

[52]Evonik Industries AG, "AEROSIL fumed silica," 2010. [Online]. Available: http://www.aerosil.com. [Accessed: 18-Apr-2017].

[53]Evonik Industries AG, "Highly dispersible silica," 2010. [Online]. Available: http://ultrasil.evonik.com. [Accessed: 18-Apr-2017].

[54]PPG Industries Inc., "PPG Precipitated Silica for Industrial Rubber Applications," 2014. [Online]. Available: https://goo.gl/DNfTRW. [Accessed: 05-May2016].

[55]Glassven, "RUBERSIL." [Online]. Available: http://www.glassven.com. [Accessed: 12-Dec-2016].

[56]Cabot, "Silicone rubbers," 2017. [Online]. Available: http://www.cabotcorp.com/.

[57]Huber Corporation, "Huber precipitated silica for rubber applications," 2016. [Online]. Available: www.hubermaterials.com. [Accessed: 19-Apr-2017]. 
[58]A. A. A. Abuelnuor, M. A. Wahid, S. E. Hosseini, A. Saat, K. M. Saqr, H. H. Sait, and M. Osman, "Characteristics of biomass in flameless combustion: A review," Renew. Sustain. Energy Rev., vol. 33, pp. 363370,2014

[59]The Japan Institue of Energy, "Thermochemical conversion of biomass," in The Asian Biomass Handbookandbook, S. Yokoyama, Ed. 2008, pp. 94-116.

[60]S. K. Chopra, S. C. Ahluwalis, and S. Laxmi, "Technology and manufacture of rice-husk ash masonry (RHAM) cement," in Proceedings of ESCAP/ RCTT Workshop on Rice-Husk Ash Cement, 1981.

[61]M. A. Hamad and I. A. Khattab, "Effect of the combustion process on the structure of rice hull silica," Thermochim. Acta, vol. 48, no. 3, pp. 343-349, 1981.

[62]H. P. Boehm, "Chemical Identification of Surface Groups,” Adv. Catal., vol. 16, pp. 179-274, 1966.

[63]J. Alvarez, G. Lopez, M. Amutio, J. Bilbao, and M. Olazar, "Bio-oil production from rice husk fast pyrolysis in a conical spouted bed reactor," Fuel, vol. 128, pp. 162169, Jul. 2014.

[64]I. A. Rahman and F. L. Riley, "The control of morphology in silicon nitride powder prepared from rice husk," J. Eur. Ceram. Soc., vol. 5, no. 1, pp. 11-22, Jan. 1989.

[65]X. Zhang, S. Zhang, H. Yang, J. Shao, Y. Chen, Y. Feng, X. Wang, and H. Chen, "Effects of hydrofluoric acid pre-deashing of rice husk on physicochemical properties and $\mathrm{CO} 2$ adsorption performance of nitrogenenriched biochar," Energy, vol. 91, pp. 903-910, Nov. 2015.

[66]T. K. Naiya, A. K. Bhattacharya, S. Mandal, and S. K. Das, "The sorption of lead(II) ions on rice husk ash.," J. Hazard. Mater., vol. 163, no. 2-3, pp. 1254-64, Apr. 2009.

[67]A. Behnood, M. Modiri Gharehveran, F. Gozali Asl, and M. Ameri, "Effects of copper slag and recycled concrete aggregate on the properties of CIR mixes with bitumen emulsion, rice husk ash, Portland cement and fly ash," Constr. Build. Mater., vol. 96, pp. 172-180, Oct. 2015.

[68]K. K. Alaneme and K. O. Sanusi, "Microstructural characteristics, mechanical and wear behaviour of aluminium matrix hybrid composites reinforced with alumina, rice husk ash and graphite," Eng. Sci. Technol. an Int. J., vol. 18, no. 3, pp. 416-422, Sep. 2015.

[69]C. Santasnachok, W. Kurniawan, and H. Hinode, "The use of synthesized zeolites from power plant rice husk ash obtained from Thailand as adsorbent for cadmium contamination removal from zinc mining," $J$. Environ. Chem. Eng., vol. 3, no. 3, pp. 2115-2126, Sep. 2015.

[70]W. Xu, Y. T. Lo, D. Ouyang, S. A. Memon, F. Xing, W. Wang, and X. Yuan, "Effect of rice husk ash fineness on porosity and hydration reaction of blended cement paste," Constr. Build. Mater., vol. 89, pp. 90-101, Aug. 2015.

[71]F. Bondioli, F. Andreola, L. Barbieri, T. Manfredini, and A. M. Ferrari, "Effect of rice husk ash (RHA) in the synthesis of (Pr,Zr)SiO4 ceramic pigment," J. Eur. Ceram. Soc., vol. 27, no. 12, pp. 3483-3488, Jan. 2007.

[72]B. . Jenkins, L. . Baxter, and T. . Miles, "Combustion properties of biomass," Fuel Process. Technol., vol. 54, no. 1-3, pp. 17-46, Mar. 1998.

[73]H. T. Le and H.-M. Ludwig, "Effect of rice husk ash and other mineral admixtures on properties of selfcompacting high performance concrete," Mater. Des., vol. 89, pp. 156-166, Jan. 2016.

[74]K. Ganesan, K. Rajagopal, and K. Thangavel, "Rice husk ash blended cement: Assessment of optimal level of replacement for strength and permeability properties of concrete," Constr. Build. Mater., vol. 22, no. 8, pp. 16751683, Aug. 2008.

[75]Z. A. M. Ishak and A. A. Bakar, "An investigation on the potential of rice husk ash as fillers for epoxidized natural rubber (ENR)," Eur. Polym. J., vol. 31, no. 3, pp. 259-269, Mar. 1995.

[76]H. Ismail, M. . Nasaruddin, and H. . Rozman, "The effect of multifunctional additive in white rice husk ash filled natural rubber compounds," Eur. Polym. J., vol. 35, no. 8, pp. 1429-1437, Aug. 1999.

[77]S. Sankar, S. K. Sharma, N. Kaur, B. Lee, D. Y. Kim, $\mathrm{S}$. Lee, and H. Jung, "Biogenerated silica nanoparticles synthesized from sticky, red, and brown rice husk ashes by a chemical method," Ceram. Int., vol. 42, no. 4, pp. 4875-4885, 2016.

[78]A. Kumar, S. Singha, D. Dasgupta, S. Datta, and T. Mandal, "Simultaneous recovery of silica and treatment of rice mill wastewater using rice husk ash: An economic approach," Ecol. Eng., vol. 84, pp. 29-37, 2015. 
[79]D. R. Paul and L. M. Robeson, "Polymer nanotechnology: Nanocomposites," in Polymer, vol. 49, no. 15,2008 , pp. 3187-3204.

[80]J. C. Posada-correa, L. Y. Jaramillo-zapata, P. A. Villegas-bolaños, L. A. García, and C. A. Vargas-isaza, "Estudio comparativo de negro de humo y alúmina como cargas reforzantes en mezclas de caucho natural," Rev. la Fac. Ing. Fis., vol. 13, no. 2, pp. 59-67, 2014.

[81]H. M. Da Costa, L. L. Y. Visconte, R. C. R. Nunes, and C. R. G. Furtado, "Rice-husk-ash-filled natural rubber. II. Partial replacement of commercial fillers and the effect on the vulcanization process," J. Appl. Polym. Sci., vol. 87, no. 9, pp. 1405-1413, Feb. 2003.

[82]H. M. Da Costa, L. L. Y. Visconte, R. C. R. Nunes, and C. R. G. Furtado, "Rice husk ash filled natural rubber. I. Overall rate constant determination for the vulcanization process from rheometric data," J. Appl. Polym. Sci., vol. 87, no. 8, pp. 1194-1203, Feb. 2003.

[83]H. M. Da Costa, L. L. Y. Visconte, R. C. R. Nunes, and C. R. G. Furtado, "Mechanical and dynamic mechanical properties of rice husk ash-filled natural rubber compounds," J. Appl. Polym. Sci., vol. 83, no. 11, pp. 2331-2346, Mar. 2002.

[84]M. Y. A. Fuad, Z. Ismail, M. S. Mansor, Z. a. M. Ishak, and a. K. M. Omar, "Mechanical Properties of Rice Husk Ash/Polypropylene Composites.," Polym. J., vol. 27, pp. 1002-1015, 1995.

[85]H. Ismail, L. Mega, and H. P. S. Abdul Khalil, "Effect of a silane coupling agent on the properties of white rice husk ash-polypropylene/natural rubber composites," Polym. Int., vol. 50, no. 5, pp. 606-611, 2001.

[86]H. E. Haxo and P. K. Mehta, "Ground Rice-Hull Ash as a Filler for Rubber," in Rubber Chemistry and Technology, vol. 48, no. 2, California: Rubber Division, ACS, 1975, pp. 271-288.

[87]D. C. Edwards, "Polymer-filler interactions in rubber reinforcement," J. Mater. Sci., vol. 25, no. 10, pp. 41754185, 1990.

[88]D. Nwabunma, "Overview of Polyolefin Composites," in Polyolefin Composites, John Wiley \& Sons, Inc., 2007, pp. 1-28.

[89]Gelest Inc., "Silane Coupling Agents: Connecting Across Boundaries," 2014.
[90]R. Pfaendner, "Nanocomposites: Industrial opportunity or challenge?," Polym. Degrad. Stab., vol. 95, no. 3, pp. 369-373, Mar. 2010.

[91]S. F. Thames and K. G. Panjnani, "Organosilane polymer chemistry: A review," J. Inorg. Organomet. Polym., vol. 6, no. 2, pp. 59-94, 1996.

[92]M. Y. Ahmad Fuad, R. SHIKOR, Z. A. Mohd Ishak, and A. K. Mohd Omar, "Rice husk ash as filler in polypropylene: Effect of wax and silane coupling agents," Plast. rubber Compos. Process. Appl., vol. 21, no. 4, pp. 225-235, 1994.

[93]E. P. Ayswarya, K. F. Vidya Francis, V. S. Renju, and E. T. Thachil, "Rice husk ash - A valuable reinforcement for high density polyethylene," Mater. Des., vol. 41, pp. 1-7, Oct. 2012.

[94]L. E. Nielsen, "Elastic moduli," in Mechanical properties of polymers and composites, New York: Mercel Dekker, 1974, pp. 405, 413.

[95]S. Siriwardena, H. Ismail, and U. S. Ishiaku, "Water absorption behavior and its effect on tensile properties of ethylene-propylene-diene-

terpolymer/polypropylene/filler ternary composites: A preliminary study," Polym. - Plast. Technol. Eng., vol. 41, no. 3, pp. 419-433, 2002.

[96]S. Chandrasekhar, K. G. Satyanarayana, P. N. Pramada, P. Raghavan, and N. T. Gupta, "Review Processing, properties and applications of reactive silica from rice husk - an overview," J. Mater. Sci., vol. 38, no. 15, pp. 3159-3168, 2003.

[97]A. Dorigato and A. Pegoretti, "Fracture behaviour of linear low density polyethylene - fumed silica nanocomposites," Eng. Fract. Mech., vol. 79, pp. 213224, Jan. 2012.

[98]D. M. Panaitescu, Z. Vuluga, C. Radovici, and C. Nicolae, "Morphological investigation of PP/nanosilica composites containing SEBS," Polym. Test., vol. 31, no. 2, pp. 355-365, Apr. 2012.

[99]C. Wu, M. Zhang, M. Rong, and K. Friedrich, "Silica nanoparticles filled polypropylene: effects of particle surface treatment, matrix ductility and particle species on mechanical performance of the composites," Compos. Sci. Technol., vol. 65, no. 3-4, pp. 635-645, Mar. 2005.

[100] K. A. Iyer and J. M. Torkelson, "Novel, synergistic composites of polypropylene and rice husk ash: Sustainable resource hybrids prepared by solid-state 
shear pulverization," Polym. Compos., vol. 34, no. 7, pp. 1211-1221, Jul. 2013.

[101]H. M. Da Costa, L. L. Y. Visconte, R. C. R. Nunes, and C. R. G. Furtado, "The effect of coupling agent and chemical treatment on rice husk ash-filled natural rubber composites," J. Appl. Polym. Sci., vol. 76, no. 7, pp. 1019-1027, 2000.

[102]H. Ismail, M. . Nasaruddin, and U. . Ishiaku, "White rice husk ash filled natural rubber compounds: the effect of multifunctional additive and silane coupling agents," Polym. Test., vol. 18, no. 4, pp. 287-298, Jun. 1999.

[103] W. Arayapranee, N. Na-Ranong, and G. L. Rempel, "Application of rice husk ash as fillers in the natural rubber industry," J. Appl. Polym. Sci., vol. 98, no. 1, pp. 34-41, Oct. 2005.

[104]F. Yatsuyanagi, N. Suzuki, M. Ito, and H. Kaidou, "Effects of Surface Chemistry of Silica Particles on the Mechanical Properties of Silica Filled Styrene-Butadiene Rubber Systems," Polym. J., vol. 34, no. 5, pp. 332-339, 2002.

[105]S. J., O. S., and I. M., "Effects of silanol group on the hybridization of rubber and silica," Kobunshi ronbunshu, vol. 57, no. 6, pp. 356-362, 2000. 